\title{
JENIUS
}

\section{Pengaruh Gaya Kepemimpinan dan Disiplin Kerja Terhadap Kinerja Karyawan Pada CV. Usaha Mandiri Jakarta}

Denok Sunarsi, S.Pd., M.M.,CHt.

Dosen Fakultas Ekonomi Universitas Pamulang

Email : denoksunarsi@gmail.com

\begin{abstract}
ABSTRAK
Penelitian ini bertujuan untuk mengetahui seberapa besar pengaruh gaya kepemimpinan (X1) terhadap kinerja karyawan CV. Usaha Mandiri (Y), dan untuk mengetahui seberapa besar pengaruh disiplin (X2) terhadap kinerja karyawan CV. Usaha Mandiri (Y).serta untuk mengetahui seberapa besar pengaruh gaya kepemimpinan (X1) dan disiplin (X2) terhadap kinerja karyawan CV. Usaha Mandiri (Y) secara simultan.

Metode penelitian ini menggunakan metode kuantitatif dengan teknik penyebaran kuisioner untuk mendapatkan data primer kepada karyawan CV.Usaha Mandiri dengan penarikan sample jenuh sebanyak 65 responden.

Hasil analisis simultan membuktikan Gaya Kepemimpinan dan Disiplin Kerja terbukti secara bersama-sama berpengaruh positif dan signifikan terhadap Kinerja dengan nilai $F$ hitung sebesar 84.470 lebih besar dari pada $F$ tabel sebesar 2,76 atau persamaannya $84.470>2,76$ sedangkan $\mathrm{p}$ - valuenya lebih kecil dari 0,05 atau sebesar 0,000 dengan persamaan 0,05>0,00 dengan nilai koefisien determinasi sebesar $72,3 \%$ maka sesuai dengan pengukuran standar uji simultan yaitu Ha diterima dan Ho ditolak.
\end{abstract}

\section{Kata Kunci : Gaya Kepemimpinan, Disiplin Kerja, Kinerja}




\section{PENDAHULUAN}

\section{Latar Belakang}

Pesatnya perkembangan ilmu pengetahuan dan teknologi, menciptakan struktur baru, yaitu struktur global. Struktur tersebut akan mengakibatkan semua bangsa di dunia termasuk Indonesia, mau tidak mau akan terlibat dalam suatu tatanan global yang seragam, pola hubungan dan pergaulan yang seragam khususnya dibidang ilmu pengetahuan dan teknologi. Aspek Ilmu Pengetahuan dan Teknologi (IPTEK) yang semakin pesat terutama teknologi komunikasi dan transportasi, menyebabkan issu-issu global tersebut menjadi semakin cepat menyebar dan menerpa pada berbagai tatanan, baik tatanan politik, ekonomi, sosial budaya maupun pertahanan keamanan. Dengan kata lain globalisasi yang ditunjang dengan pesat ilmu pengetahuan dan teknologi telah menjadikan dunia menjadi transparan tanpa mengenal batas-batas negara. Dengan perkembangan teknologi yang begitu pesat, masyarakat dunia khususnya masyarakat Indonesia terus berubah sejalan dengan perkembangan teknologi, dari masyarakat pertanian ke masyarakat industri dan berlanjut ke masyarakat pasca industri yang serba teknologis. Pencapaian tujuan dalam bidang politik, ekonomi, sosial budaya dan pertahanan keamanan cenderung akan semakin ditentukan oleh penguasaan teknologi dan informasi, walaupun kualitas sumber daya manusia (SDM) masih tetap yang utama.

Mengingat pentingnya masalah tersebut, dan untuk menyikapi kondisi tersebut diatas, maka dilakukan penelitian dengan judul "Pengaruh Gaya Kepemimpinan, Dan Disiplin Kerja Terhadap Kinerja Karyawan CV. Usaha Mandiri".

\section{Batasan Masalah}

Pada penelitian ini penulis membatasi masalah yang akan diteliti pada hubungan gaya kepemimpinan dan disiplin dengan kinerja karyawan .

Gaya kepemimpinan adalah kemampuan seseorang dalam mengarahkan, mempengaruhi, mendorong dan mengendalikan orang lain atau bawahan untuk bisa melakukan sesuatu pekerjaan atas kesadarannya dan sukarela dalam mencapai suatu tujuan tertentu.

Disiplin sebagai kegiatan manajemen untuk menjalankan standar-standar organisasional. Kegiatan yang dilaksanakan untuk mendorong para karyawan agar mengikuti berbagai standar dan aturan, sehinga penyelewenganpenyelewengan dapat dicegah (Handoko, 2012:208).

Kinerja

adalah pencapaian/prestasi seseorang berkenaan dengan tugas-tugas yang dibebankan kepadanya.Kinerja juga pula dipandang sebagai perpaduan dari hasil kerja (apayang harus dicapai seseorang) dan kompetensi (bagaimana seseorang mencapainya). (Marwansyah, 2012:228)

Kinerja kepemimpinan dibatasi pada fungsi dan tugasnya dalam pelaksanaan penggunaan pengaruh, profesional, pemberdayaan, mobilitas, motivasi, pengarahan dan bimbingan, serta pembentukan komitmen. Kinerja manajemen pada aspek keterbukaan, kemandirian, 
kerjasama, akuntanbilitas dan sustainbilitas.

Penelitian dilaksanakan di CV. Usaha Mandiri. Jakarta, Alamat Jl. Sabar Raya No.14 RT. 09 / RW. 04 Petukangan Selatan Jakarta Selatan 12270.

Penelitian dilaksanakan pada tanggal mulai tanggal 1 Januari 2017 sampai dengan 30 Maret 2017.

\section{Rumusan Masalah}

Adapun rumusan masalahnya adalah:
1. Bagaimana pengaruh gaya kepemimpinan (X1) terhadap kinerja karyawan $\mathrm{CV}$. Usaha Mandiri (Y)?.

2. Bagaimana pengaruh disiplin (X2) terhadap kinerja karyawan CV. Usaha Mandiri (Y)?.

3. Bagaimana pengaruh gaya kepemimpinan (X1) dan disiplin (X2) terhadap kinerja karyawan CV. Usaha Mandiri (Y) secara simultan?.

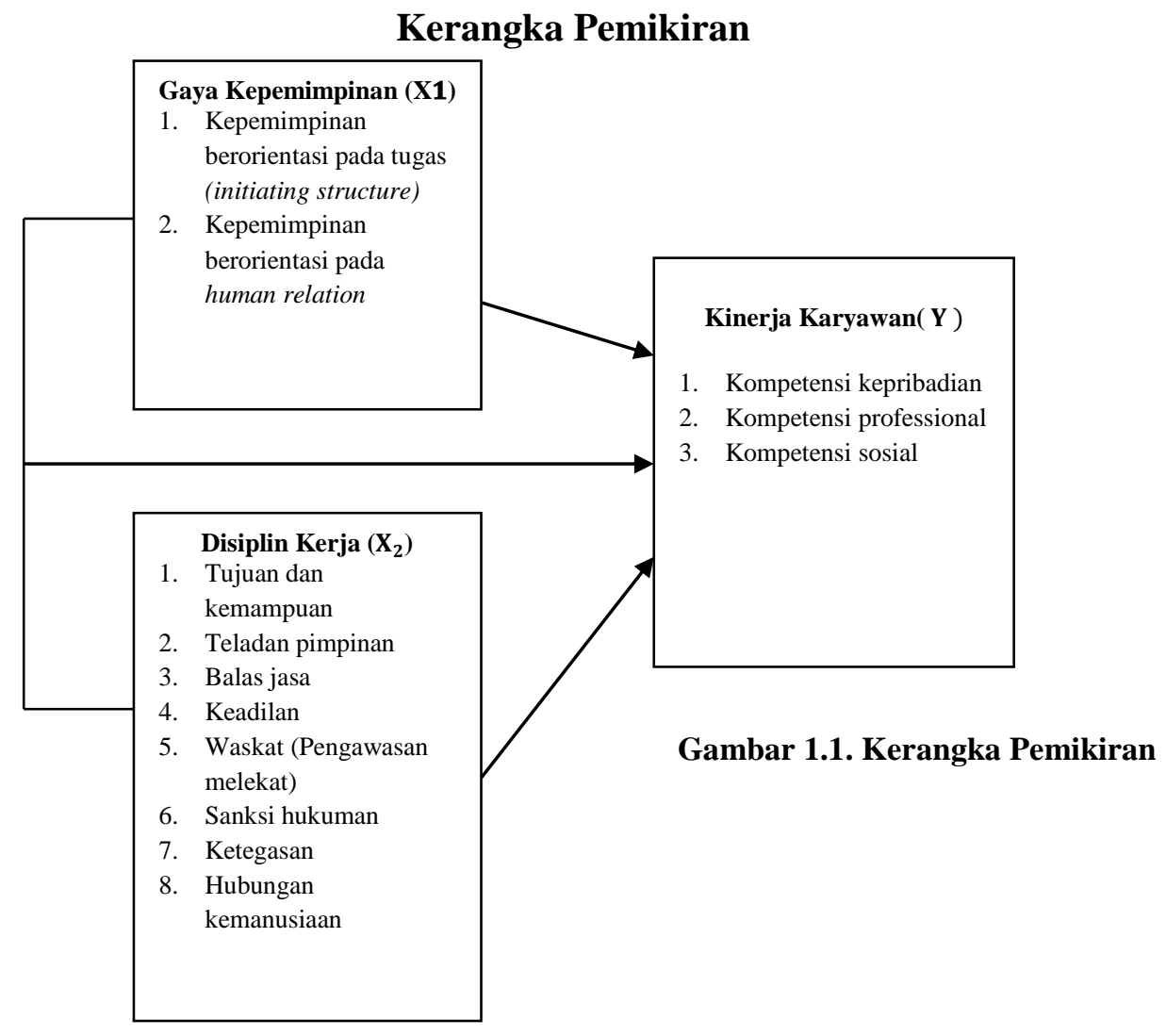

\section{Tujuan Penelitian}

Tujuan penelitian ini adalah :

1. Untuk mengetahui seberapa besar pengaruh gaya kepemimpinan (X1) terhadap kinerja karyawan CV. Usaha Mandiri (Y).

2. Untuk mengetahui seberapa besar pengaruh disiplin (X2) terhadap kinerja karyawan CV. Usaha Mandiri (Y).

3. Untuk mengetahui seberapa besar pengaruh gaya kepemimpinan (X1) dan disiplin (X2) terhadap kinerja karyawan CV. Usaha Mandiri (Y)secara simultan. 


\section{Hipotesa Penelitian}

Berdasarkan

kerangka

pemikiran diatas, maka dapat diajukan suatu hipotesa penelitian, yaitu:

$\mathrm{H} 1=$ Diduga terdapat pengaruh positif dan signifikan gaya kepemimpinan (X1) terhadap kinerja karyawan CV. Usaha Mandiri (Y)

$\mathrm{H} 2=$ Diduga terdapat pengaruh positif dan signifikan Disiplin (X2) terhadap kinerja karyawan $\mathrm{CV}$. Usaha Mandiri (Y)

H3 = Diduga terdapat pengaruh positif dan signifikan antara gaya kepemimpinan (X1), dan Disiplin Kerja (X2), terhadap kinerja karyawan CV. Usaha Mandiri. (Y).

\section{LANDASAN TEORI \\ Gaya Kepemimpinan}

Kepemimpinan merupakan tulang punggung pengembangan organisasi karena tanpa kepemimpinan yang baik akan sulit mencapai tujuan organisasi. Jika seorang pemimpin berusaha untuk mempengaruhi perilaku orang lain, maka orang tersebut perlu memikirkan gaya kepemimpinannya.

Gaya kepemimpinan adalah perilaku dan strategi, sebagai hasil kombinasi dari falsafah, ketrampilan, sifat, sikap, yang sering diterapkan seorang pemimpin ketika ia mencoba mempengaruhi kinerja bawahannya (Tampubolon, 2007:9).

Berdasarkan definisi gaya kepemimpinan diatas dapat disimpulkan bahwa kepemimpinan adalah kemampuan seseorang dalam mengarahkan, mempengaruhi, mendorong dan mengendalikan orang lain atau bawahan untuk bisa melakukan sesuatu pekerjaan atas kesadarannya dan sukarela dalam mencapai suatu tujuan tertentu.

\section{Disiplin Kerja}

'(Handoko,

2012:208)

mendefinisikan disiplin sebagai

kegiatan manajemen untuk

menjalankan standar-standar

organisasional. Kegiatan yang dilaksanakan untuk mendorong para karyawan agar mengikuti berbagai standar dan aturan, sehinga penyelewengan-penyelewengan dapat dicegah.

Hakikat disiplin menurut (Heijrachman dan Husnan dalam Sinambela, 2012:238) adalah setiap perseorangan dan juga kelompok yang menjamin adanya kepatuhan terhadap perintah.

\section{Kinerja}

(Sinambela, dkk., 2011: 136) mengemukakan bahwa kinerja pegawai didefinisikan sebagai kemampuan pegawai dalam melakukan sesuatu keahlian tertentu. Kinerja pegawai sangatlah perlu, sebab dengan kinerja ini akan diketahui seberapa jauh kemampuan pegawai dalam melaksanakan tugas yang dibebankan kepadanya. Untuk $\mathrm{du}$ diperlukan penentuan kriteria yang jelas dan terukur serta ditetapkan secara bersama-sama yang dijadikan sebagai acuan

\section{Pengaruh Gaya Kepemimpinan dan Disiplin Kerja Terhadap Kinerja}

Gaya kepemimpinan dan disiplin kerja karyawan diindikasikan memiliki pengaruh yang secara bersama-sama (simultan) terhadap kinerja dari karyawan CV. Usaha mandiri. Tingkat ketidakhadiran karyawan yang cukup tinggi dan sikap pemimpin yang kurang tegas dalam memberi sanksi kepada 
karyawan yang tidak disiplin menyebabkan target yang telah ditetapkan oleh perusahaan tidak dapat selesai tepat pada waktunya. Hal ini juga menimbulkan kecemburuan sosial antar karyawan.

Hal ini mengindikasikan bahwa gaya kepemimpinan dan disiplin kerja, kedua variabel tersebut berdampak atau menimbulkan pengaruh terhadap menurunnya kinerja karyawan CV. Usaha mandiri. Gaya kepemimpinan yang tepat serta didukung dengan karyawan yang disiplin akan mampu menyelesaikan target kerja yang telah ditetapkan oleh perusahaan. Target penjualan akan terpenuhi dan stabil dalam setiap bulannya. Selain itu, karyawan juga akan merasa lebih nyaman dalam bekerja. Hal ini juga akan meningkatkan motivasi dan semangat kerja dari karyawan. Dengan demikian, gaya kepemimpinan dan disiplin kerja yang tinggi yang tepat akan membuat kinerja karyawan menjadi lebih optimal. Sehingga, dengan optimalnya kinerja karyawan akan membawa perusahaan mencapai visi yang telah ditetapkan.

\section{METODOLOGI PENELITIAN}

\section{A. Metode Penelitian}

Penelitian yang dilakukan penulis pada karyawan $\mathrm{CV}$. Usaha Mandiri Jakarta, dilakukan dengan menggunakan metode Deskriptif dengan teknik survey, yang dalam hal ini pengertian deskriptif menurut Winarno Surakhmad (2005 : 139) bahwa :

'Penyelidikan deskriptif tertuju pada pemecahan masalah yang ada pada masa sekarang. Karena banyak sekali ragam penyelidikan demikian, metode penyelidikan deskriptif lebih merupakan istilah umum yang mencakup berbagai teknik deskriptif, diantaranya ialah penyelidikan yang menuturkan, menganalisa, dan mengklasifikasikan penyelidikan dengan teknik survey, interview, angket, observasi, atau teknik test'.

Berdasarkan pengertian tersebut, penelitian yang dilakukan penulis dengan cara melihat langsung kegiatan yang dilakukan pada obyek penelitian, mencatat, menganalisis, menyimpulkan, serta menggunakannya sebagai bahan penyusunan skripsi ini.

Pendekatan analisis yang dipakai dalam penelitian ini adalah menggunakan pendekatan kuantitatif, jenis statistik yang dipakai dalam penelitian adalah statistik non parametrik. Menurut Sugiyono (2007:224):

"Statistik non parametrik digunakan untuk menguji hipotesis bila datanya berbentuk nominal atau ordinal, dan tidak berlandaskan asumsi bahwa distribusi data harus normal".

Peneliti menggunakan statistik nonparametrik karena data yang diolah berbentuk ordinal.

\section{B. Operasionalisasi Variabel}

Istilah "Variabel" merupakan istilah yang tidak pernah ketinggalan dalam setiap jenis penelitian, F.N. Kerlinger dalam Suharsimi Arikunto (2006:116) menyebut variabel sebagai sebuah konsep.

Dalam penelitian ini, variabel-variabel yang akan diteliti adalah :

1. Variabel $\mathrm{X}$ atau yang disebut variabel bebas (independen varible), varibel bebas 
merupakan variabel yang mempengaruhi variabel lain. Dalam penelitian ini yang merupakan variabel bebas adalah gaya kepemimpinan dan Disiplin Kerja

2. Variabel $\mathrm{Y}$ atau yang disebut dengan variabel terikat (dependen variabel), variabel terikat merupakan variabel yang dipengaruhi oleh variabel lain. Dalam penelitian ini yang merupakan variabel terikat adalah kinerja.

\section{Skala Pengukuran dan Macam Data Penelitian \\ 1. Skala Pengukuran}

Pada penelitian ini penulis menggunakan Skala Likert. Definisi Skala Likert menurut Sugiyono (2007:86)

"Skala Likert digunakan untuk mengukur sikap, pendapat, dan persepsi seseorang atau sekelompok orang tentang fenomena sosial“"

Dalam penelitian fenomena sosial ini telah ditetapkan spesifik oleh peneliti, yang selanjutnya disebut variabel penelitian, dimana variabel $\mathrm{X} 1$ disini adalah gaya kepemimpinan dan variabel X2 adalah disiplin kerja, serta Variabel $\mathrm{Y}$ adalah kinerja.

Dalam skala ini responden diminta untuk membubuhkan tanda checklist $(\sqrt{ })$ pada salah satu dari lima kemungkinan jawaban yang tersedia, dengan lima penilaian sebagai berikut:

Tabel 3.2

Skala Likert

\begin{tabular}{|c|c|}
\hline Pernyataan Responden & Skor \\
\hline Sangat Setuju (SS) & 5 \\
\hline Setuju (S) & 4 \\
\hline
\end{tabular}

\begin{tabular}{|c|c|}
\hline Ragu-ragu (R) & 3 \\
\hline Tidak Setuju (TS) & 2 \\
\hline Sangat Tidak Setuju (STS) & 1 \\
\hline \multicolumn{2}{|c|}{ Sumber: Sugiyono (2007:87) }
\end{tabular}

\section{Macam Data Penelitian}

Dikarenakan Penulis menggunakan statistik nonparametris untuk analisis datanya maka macam data penelitian harus dalam bentuk ordinal (Sugiyono, 2007:146). Dimana menurut Sugiyono (2007:15) : "Data-data yang diperoleh dari pengukuran dengan instrumen sikap dengan Skala Likert misalnya adalah berbentuk data interval"

Berdasarkan pendapat tersebut maka penulis mengubah data interval menjadi data ordinal dengan merubah jumlah nilai skor dari Skala Likert dalam bentuk ranking untuk analisis pengolahan data untuk mengetahui hubungan variabel X dengan Variabel Y

\section{Teknik Pengumpulan Data}

Adapun data untuk penyusunan penelitian ini diperoleh dengan melalui pengumpulan data primer dan data sekunder.

1. Data Primer

Definisi data primer menurut Soeratmo \& Lincolin Arsyad (2005:76) adalah:

"Data yang dikumpulkan dan diolah sendiri oleh organisasi yang menerbitkan atau menggunakannya"

2. Data Sekunder

Definisi data sekunder menurut Soeratmo \& Lincolin Arsyad (2005:76):

"Data yang diterbitkan atau digunakan oleh organisasi yang bukan pengolahnya". 
Untuk mendapatkan data yang diperlukan, penyusun menggunakan teknik pengumpulan data melalui:

$\begin{array}{lrr}\text { a. Penelitian } & \text { Lapangan } & \text { (Field } \\ \text { Research) } & & \\ \text { Penelitian } & \text { dilakukan } & \text { pada } \\ \text { karyawan } & \text { CV. Usaha Mandiri }\end{array}$ Jakarta. Teknik pengumpulan data yang digunakan penulis adalah sebagai berikut:

- Observasi, yaitu dengan melakukan pengamatan langsung ke objek yang dijadikan sasaran peneliti berfungsi sebagai pengumpulan data, sedangkan pihak-pihak yang dihubungi sebagai pemberi data atau sumber data bagi peneliti.

- Kuesioner/ angket, yaitu membagi angket/ kuesioner kepada karyawan CV. Usaha Mandiri Jakarta, dimana angket ini berisi tentang pertanyaan mengenai Gaya Kepemimpinan (X1) dan Disiplin Kerja (X2) serta Kinerja (Y).

b. Penelitian Kepustakaan (Library Research)

Penelitian teoritis dengan membaca catatan, literatur dan sumber-sumber lainnya yang ada hubungannya dengan masalah yang dibahas atau yang sesuai dengan kebutuhan.

\section{E. Populasi dan Sampel}

Besaran populasi menurut pendapat Sugiyono (2007:72), yang menyatakan bahwa:

"Populasi adalah wilayah generalisasi yang terdiri atas: Obyek/ subyek yang mempunyai kualitas dan karakteristik tertentu yang ditetapkan oleh peneliti untuk dipelajari dan kemudian ditarik kesimpulannya".

Populasi adalah gabungan dari seluruh elemen yang berbentuk peristiwa, hal, atau orang yang memiliki karakteristik serupa yang menjadi pusat perhatian peneliti, karenanya dipandang sebagai semesta penelitian (Ferdianad, 2006:57). Populasi dalam penelitian ini adalah seluruh karyawan CV. Usaha Mandiri Jakarta.

Yang dimaksud sampel menurut Sugiyono (2007:73) adalah:"Sampel adalah bagian dari jumlah karakteristik yang dimiliki oleh populasi tersebut".Sampel merupakan subset dari populasi, terdiri dari beberapa anggota populasi Dalam penelitian ini tidak digunakan teknik sampling karena sampel yang diteliti adalah keseluruhan dari populasi yang ada atau disebut dengan sensus. Mengingat jumlah populasi hanya sebesar 65 karyawan, maka layak untuk diambil keseluruhan untuk dijadikan sampel tanpa harus mengambil sampel dalam jumlah tertentu. Sehingga sampel dari penelitian ini adalah seluruh karyawan CV Usaha Mandiri Jakarta. Total keseluruhan berjumlah 65 orang karyawan.

Berdasarkan perhitungan tersebut maka responden yang diambil untuk sampel penelitian adalah sebanyak 65 responden.

\section{F. Teknik Pengolahan Data}

Teknik pengolahan data dalam penelitian ini mengikuti langkah-langkah sebagai berikut:

1. Untuk menjawab identifikasi masalah pertama, kedua dan ketiga yaitu bagaimana 
pelaksanaan gaya kepemimpinan dan disiplin kerja serta bagaimana kinerja dengan melakukan pembagian kuesioner yang kemudian diolah dalam bentuk persentase jawaban yang diperoleh dari nilai skor aktual dibagi dengan skor ideal kemudikan dikalikan $100 \%$.

2. Uji Validitas dan Reliabilitas Uji validitas atau keshahihan digunakan untuk mengetahui seberapa tepat suatu alat ukur mampu melakukan fungsi. Alat ukur yang dapat digunakan dalam pengujian validitas suatu kuesioner adalah angka hasil korelasi antara skor pernyataan dan skor keseluruhan pernyataan responden terhadap infomasi dalam kuesioner. Jenis korelasi yang digunakan adalah korelasi Pearson antara skor setiap pertanyaan dan skor aktual item. Cara memperoleh angka korelasi dalam uji validitas dengan alat bantu software SPSS sering dilakukan dengan dua alternatif. Alternatif pertama pengujian validitas dengan SPSS 22.0 adalah menggunakan angka $r$ hasil korelasi pearson yang dihasilkan melalui sub menu correlate pada pilihan Bivariaten, sedangkan alternatif kedua adalah menggunakan nilai $\mathrm{r}$ hasil Corrected Item Total Correlation melalui sub menu Scalepada pilihan Reliability Analysis. Pada penelitian ini penulis menggunakan alternatif yang kedua.

Setelah pengujian validitas, selanjutnya dilakukan pengujuan reliabilitas. Tujuan utama pengujian reliabilitas adalah untuk mengetahui konsistensi atau keteraturan hasil pengukuran suatu instrumen apabila instrumen tersebut digunakan lagi sebagai alat ukur suatu objek atau responden. Hasil uji reliabilitas mencerminkan dapat dipercaya dan tidaknya suatu instrumen penelitian berdasarkan tingkat kemantapan dan ketepatan suatu alat ukur dalam pengertian bahwa hasil pengukuran yang didapatkan merupakan ukuran yang benar dari sesuatu yang diukur.

Salah satu metode pengujian reliabilitas yang digunakan adalah dengan menggunakan metode Alpha-Cronbach. Standar yang digunakan dalam menentukan reliabel dan tidaknya suatu instrumen penelitian umumnya adalah perbandingan antara nilai $r$ hitung dengan $r$ tabel pada taraf kepercayaan $95 \%$ atau tingkat signifikasi $5 \%$. Apabila dilakukan pengujian reliabilitas dengan metode ini, maka nilai $r$ hitung diwakili oleh nilai alpha. Menurut Santoso (2002), apabila alpha hitung lebih besar daripada $r$ tabel dan alpha hitung bernilai positif, maka suatu instrumen penelitian dapat disebut reliabel.

3. Untuk menjawab identifikasi masalah ketiga, yaitu seberapa besar hubungan pengendalian kerja dengan prestasi kerja akan diuraikan melalui perhitungan koefisien korelasi dengan menggunakan analisis koefisien korelasi Rank Spearman (rs) karena data berbentuk ordinal dengan jenis statistik yaitu statistik non parametrik, 
dilanjutkan dengan analisis koefisien determinasi dan uji hipotesis.

Koefisien Korelasi Rank Spearman

Koefisien korelasi antara kedua variabel data, dengan menggunakan koefisien korelasi Spearman (rs). dengan rumus Siegel (2005):

$r s=1-\frac{6 \sum_{i=1}^{n} d i^{2}}{n^{3}-n}$

Keterangan:

di $=$ perbedaan antara jenjang ke-I dari masing-masing kelompok

$\mathrm{n}$ = banyaknya sampel

rs $=$ koefisien korelasi

$\mathrm{i}=$ kelas interval

Jika terdapat ranking yang berangka sama, maka digunakan rumus koefisien korelasi Spearman/ faktor koreksi dengan rumus:

$T=\frac{t^{3}-t}{12}$

dimana: $\quad \mathrm{T}=$ faktor koreksi

$\mathrm{t}=$ banyaknya angka

observasi yang beraneka ragam

Sehingga analisis korelasi rank spearman menjadi:

$$
r s=\frac{\sum X^{2}+\sum Y^{2}-\sum d i^{2}}{2 \sqrt{\sum X^{2} \sum Y^{2}}}
$$

Dengan ketentuan:

$$
\begin{aligned}
& \sum X^{2}=\frac{n^{3}-n}{12}-\sum T_{X} \\
& \sum Y^{2}=\frac{n^{3}-n}{12}-\sum T_{Y}
\end{aligned}
$$

Untuk menentukan kuat atau lemahnya koefisien korelasi, maka dapat mengikuti batasanbatasan sebagai berikut: Tabel 3.3
Interpretasi Koefisien Korelasi

\begin{tabular}{|l|c|}
\hline Nilai & Interpretasi \\
\hline $0,00-1,99$ & Sangat rendah \\
$0,20-0,399$ & Rendah \\
$0,40-0,599$ & Sedang \\
$0,60-0,799$ & Kuat \\
$0,80-1,000$ & Sangat kuat \\
\hline
\end{tabular}

Sumber: Sugiyono, 2007:183

\section{Koefisien Determinasi}

Setelah itu dilanjutkan dengan mencari besarnya kontribusi variabel $\mathrm{X}$ terhadap variabel $\mathrm{Y}$ dengan menggunakan rumus Koefisien Determinasi:

$\mathrm{Kd}=(\mathrm{rs})^{2} \mathrm{X} 100 \%$

\section{G. Uji Hipotesis}

Untuk menguji hipotesis penulis menggunakan uji dua pihak. Pengujian hipotesis digunakan untuk mengetahui hubungan variabel $\mathrm{X}$ dan variabel $\mathrm{Y}$, dalam hal ini variabel $\mathrm{X}$ adalah pengendalian diri dan variabel Y adalah prestasi belajar. Statistik uji yang digunakan adalah statistik uji hitung dengan rumus:

$$
\mathrm{Uji} t=r s \sqrt{\frac{n-2}{1-r s}}
$$

Kriteria pengambilan keputusannya adalah:

Ho : Pengendalian diri tidak memiliki hubungan dengan prestasi belajar mahasiswa.

H1 : Pengendalian diri memiliki hubungan dengan prestasi belajar mahasiswa.

Hipotesis (H1) ditolak jika $\mathrm{t}$ hitung $<\mathrm{t}$ tabel. Untuk mengetahui nilai $\mathrm{t}$ tabel maka dilihat berdasarkan taraf signifikasi $5 \% \quad(\alpha=0,05)$ dan derajat kebebasan $(\mathrm{dk})=\mathrm{n}-2$, dalam hal ini lainnya hipotesis diterima, atau dengan ketentuan: 
$\mathrm{t}$ hitung $>\mathrm{t}$ tabel maka Ho ditolak dan $\mathrm{H} 1$ diterima.

$\mathrm{t}$ hitung $<\mathrm{t}$ tabel maka Ho diterima dan $\mathrm{H} 1$ ditolak.

\section{HASIL PENELITIAN}

\section{A. Gambaran Umum Obyek Penelitian}

\section{Sejarah Perusahaan}

CV. Usaha Mandiri didirikan oleh Hadi Kartini pada tahun 1989 bermula dari bisnis bordir topi. Dengan modal satu juta rupiah, hadi kartini mengembangkan bisnis topinya hingga memiliki 22 counter di Jakarta, bandung dan beberapa wilayah di Indonesia. Target pemasaran topinya berupa bodir topi perusahaan dan dikembangkan di Indonesia dan mancanegara, omzet profit bisa mencapai rp. 350 juta per bulan.

Saat ini CV. Usaha Mandiri tidak hanya menghasilkan produk topi, tetapi merambah ke bordir baju, kemeja, jaket, sweater, gravir dan lain lainnya.

a. Visi Usaha

Menjadi perusahaan yang bermutu secara kualitatif dan kuantitatif, mandiri, menguasai dan mencapai target pasar, serta dikenal luas oleh masyarakat.

b. Misi usaha
1. Melakukan
klasifikasi bahan produksi
2. Meningkatkan kualitas SDM

3. Mendesign produk dengan semenarik mungkin

4. Permodalan usaha secara mandiri

5. Menghasilkan profit

6. Memberikan pelayananan dan kepuasan terhadap konsumen

\section{B. Deskripsi Data}

1. Karakteristik Responden Berdasarkan Jenis kelamin

Tabel 4.1

Jenis Kelamin

\begin{tabular}{|l|l|l|}
\hline Jenis kelamin & Frekuensi & Persen \\
\hline Laki-laki & 38 & $58 \%$ \\
\hline Perempuan & 27 & $42 \%$ \\
\hline Total & 65 & $100 \%$ \\
\hline
\end{tabular}

Sumber : Data Primer

Berdasarkan pada tabel dan diagram di atas, diketahui bahwa responden dalam penelitian ini terdiri dari laki-laki berjumlah 38 dan responden perempuan terdiri dari 27 orang. Dimana, hal ini membuktikan bahwa laki-laki mendominasi dalam pekerjaan operational. Hal ini dikarenakan dalam segi fisik lakilaki dominan lebih kuat dari pada perempuan. Akan tetapi bukan berarti perempuan itu lemah, hanya saja di beberapa bidang pekerjaan tertentu yang membutuhkan ketahanan fisik kuat laki-laki memang lebih dominan.

2. Karakteristik Responden Berdasarkan Masa Kerja

Tabel 4. 2

Masa Kerja

\begin{tabular}{|l|l|l|}
\hline Masa kerja & Frekuensi & $\begin{array}{l}\text { Persen } \\
(\%)\end{array}$ \\
\hline $0-1$ tahun & 9 & $14 \%$ \\
\hline 1-3 tahun & 29 & $45 \%$ \\
\hline 3-5 tahun & 23 & $35 \%$ \\
\hline Di atas 5 tahun & 5 & $8 \%$ \\
\hline
\end{tabular}



\begin{tabular}{|l|l}
65 & $100 \%$ \\
\hline
\end{tabular}

Sumber : Data Primer

Dari data tabel dan diagram masa kerja di atas maka dapat diketahui bahwa responden yang berjumlah 65 orang tersebut, mempunyai frekuensi dengan rentan waktu masa kerja 1-3 tahun sebesar 45 persen (\%). Masa kerja 3-5 tahun sebesar 35 persen (\%). Masa kerja 01 tahun sebesar 14 persen (\%). Masa kerja di atas 5 tahun sebesar 8 persen (\%). Data tersebut cukup membuktikan bahwa CV. Usaha Mandiri telah memberikan kenyamanan bagi karyawankaryawannya dalam bekerja. Hal ini dapat dilihat dari jumlah rentan waktu masa kerja paling besar antara 1-3 tahun sebesar 45 persen (\%) dan yang kedua masa kerja 3-5 tahun sebesar 35 persen $(\%)$.

\section{Analisis Deskriptif}

1. Gaya Kepemimpinan

Tabel 4. 3

Jawaban Responden Gaya

Kepemimpinan $\left(\mathbf{X}_{1}\right)$

\begin{tabular}{|c|c|c|c|c|c|c|}
\hline \multirow{2}{*}{ No } & \multirow{2}{*}{ Pernyataan } & \multicolumn{5}{|c|}{ Skala Likert } \\
\hline & & SS & $\mathbf{S}$ & $\mathrm{CS}$ & TS & STS \\
\hline \multicolumn{7}{|c|}{$\begin{array}{c}\text { Kepemimpinan Beorientasi Pada Tugas (Initiating } \\
\text { structure) }\end{array}$} \\
\hline 1 & $\begin{array}{l}\text { Pemimpin } \\
\text { sering } \\
\text { menekankan } \\
\text { pentingnya } \\
\text { tugas dan } \\
\text { meminta anda } \\
\text { melaksanakan } \\
\text { tugas dengan } \\
\text { sebaik-baiknya. }\end{array}$ & 37 & 27 & 0 & 1 & 0 \\
\hline 2 & $\begin{array}{l}\text { Pimpinan } \\
\text { mempengaruhi } \\
\text { cara pandang } \\
\text { untuk } \\
\text { menyelesaikan } \\
\text { masalah } \\
\text { pekerjaan. }\end{array}$ & 28 & 35 & 1 & 1 & 0 \\
\hline 3 & $\begin{array}{l}\text { Pemimpin } \\
\text { mengkomunikasi } \\
\text { kan tujuan dan } \\
\text { memberikan } \\
\text { kesempatan bagi } \\
\text { karyawan untuk }\end{array}$ & 43 & 20 & 1 & 1 & 0 \\
\hline
\end{tabular}

\begin{tabular}{|c|c|c|c|c|c|c|c|}
\hline & \begin{tabular}{ll}
\multicolumn{2}{l}{ mencapai } \\
sesuatu dengan \\
cara & mereka \\
sendiri. & \\
\end{tabular} & & & & & & \\
\hline 4 & $\begin{array}{l}\text { Pemimpin } \\
\text { menghargai dan } \\
\text { memuji para } \\
\text { karyawan yang } \\
\text { kinerjanya bagus }\end{array}$ & 41 & 23 & 0 & 1 & 0 & \\
\hline 5 & $\begin{array}{l}\text { Pemimpin sadar } \\
\text { apabila ada } \\
\text { permasalahan } \\
\text { berusaha } \\
\text { membantu } \\
\text { dengan } \\
\text { kemampuannya } \\
\text { untuk } \\
\text { memecahkan } \\
\text { dengan baik } \\
\end{array}$ & 40 & 24 & 0 & 1 & 0 & \\
\hline & Kepemimpinan Be & orient: & Pada & Iuman & Rela & tion & \\
\hline 6 & $\begin{array}{l}\text { Pemimpin } \\
\text { pandai membuat } \\
\text { konsep/pemikira } \\
\mathrm{n} \text { yang actual }\end{array}$ & 38 & 26 & 0 & & 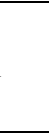 & 0 \\
\hline 7 & $\begin{array}{l}\text { Pemimpin } \\
\text { terbuka bagi } \\
\text { semua pihak } \\
\text { untuk } \\
\text { mengembangkan } \\
\text { perusahaan }\end{array}$ & 36 & 28 & 0 & & . & 0 \\
\hline 8 & $\begin{array}{l}\text { Pemimpin } \\
\text { konsisten dan } \\
\text { komit terhadap } \\
\text { kemajuan } \\
\text { karyawan }\end{array}$ & 34 & 28 & 2 & & . & 0 \\
\hline 9 & $\begin{array}{l}\text { Pemimpin } \\
\text { mampu } \\
\text { memberikan } \\
\text { keteladanan } \\
\text { yang baik } \\
\text { kepada seluruh } \\
\text { karyawan. }\end{array}$ & 32 & 32 & 0 & & . & 0 \\
\hline 10 & $\begin{array}{l}\text { Pemimpin dapat } \\
\text { menerima kritik } \\
\text { dan saran dari } \\
\text { siapapun untuku } \\
\text { kemajuan } \\
\text { perusahaan } \\
\text { bersama }\end{array}$ & 41 & 23 & 0 & & . & 0 \\
\hline \multicolumn{2}{|c|}{ Jumlah } & 370 & 266 & 4 & & 0 & 0 \\
\hline \multicolumn{2}{|c|}{ Persentasi (\%) } & $57 \%$ & $41 \%$ & $1 \%$ & & $2 \%$ & 0 \\
\hline
\end{tabular}

Sumber : Data primer

Dari tabel diatas dapat diketahui bahwa $57 \%$ responden menjawab sangat setuju, $41 \%$ responden menjawab setuju, $1 \%$ responden menjawab cukup setuju, 2\% responden menjawab tidak setuju dan $0 \%$ responden menjawab sangat tidak setuju. 
2. Disiplin Kerja

Tabel 4. 4

Jawaban Responden Disiplin Kerja ( $\left.\mathbf{X}_{2}\right)$

\begin{tabular}{|c|c|c|c|c|c|c|}
\hline \multicolumn{7}{|c|}{ awaban Responden Disıplin Kerja $\left(\mathrm{X}_{2}\right)$} \\
\hline \multirow{2}{*}{ No } & \multirow{2}{*}{ Pernyataan } & \multicolumn{5}{|c|}{ Skala Likert } \\
\hline & & SS & $\mathbf{S}$ & CS & TS & $\begin{array}{l}\text { ST } \\
\text { S }\end{array}$ \\
\hline \multicolumn{7}{|c|}{ Tujuan Dan kemampuan } \\
\hline 1 & $\begin{array}{l}\text { Saya datang } \\
\text { tepat waktu } \\
\text { dalam bekerja. }\end{array}$ & 37 & 27 & 0 & 1 & 0 \\
\hline 2 & $\begin{array}{ll}\text { Saya ikut } \\
\text { andil dalam } \\
\text { memberikan } \\
\text { kontribusi } \\
\text { dalam setiap } \\
\text { kegiatan. }\end{array}$ & 28 & 35 & 1 & 1 & 0 \\
\hline \multicolumn{7}{|c|}{ Teladan Pimpinan } \\
\hline 3 & $\begin{array}{ll}\text { Saya } & \text { secara } \\
\text { rutin } & \\
\text { mendapatkan } \\
\text { saran dan } \\
\text { arahan } & \text { dari } \\
\text { pemimpin. } & \end{array}$ & 43 & 20 & 1 & 1 & 0 \\
\hline \multicolumn{7}{|c|}{ Balas Jasa } \\
\hline 4 & $\begin{array}{lr}\text { Jarak tempat } \\
\text { tinggal dan } \\
\text { tempat kerja } \\
\text { tidak } \\
\text { mempengaruhi } \\
\text { ketepatan waktu } \\
\text { saya. } \\
\end{array}$ & 41 & 23 & 0 & 1 & 0 \\
\hline \multicolumn{7}{|c|}{ Keadilan } \\
\hline 5 & $\begin{array}{l}\text { Saya menaati } \\
\text { aturan yang ada } \\
\text { dalam } \\
\text { perusahaan. }\end{array}$ & 40 & 24 & 0 & 1 & 0 \\
\hline
\end{tabular}

Waskat (Pengawasan Melekat)

\begin{tabular}{|c|c|c|c|c|c|c|}
\hline 6 & $\begin{array}{l}\text { Absensi } \\
\text { kehadiran } \\
\text { menurut saya } \\
\text { sangat penting } \\
\text { dalam } \\
\text { penegakan } \\
\text { disiplin kerja }\end{array}$ & 38 & 26 & 0 & 1 & 0 \\
\hline 7 & $\begin{array}{ll}\text { Saya harus } \\
\text { melaksanakan } \\
\text { tugas - tugas } \\
\text { dengan } \\
\text { tanggung jawab } \\
\text { dan sesuai } \\
\text { dengan waktu } \\
\text { yang telah } \\
\text { ditentukan }\end{array}$ & 36 & 28 & 0 & 1 & 0 \\
\hline
\end{tabular}

Hubungan Kemanusiaan

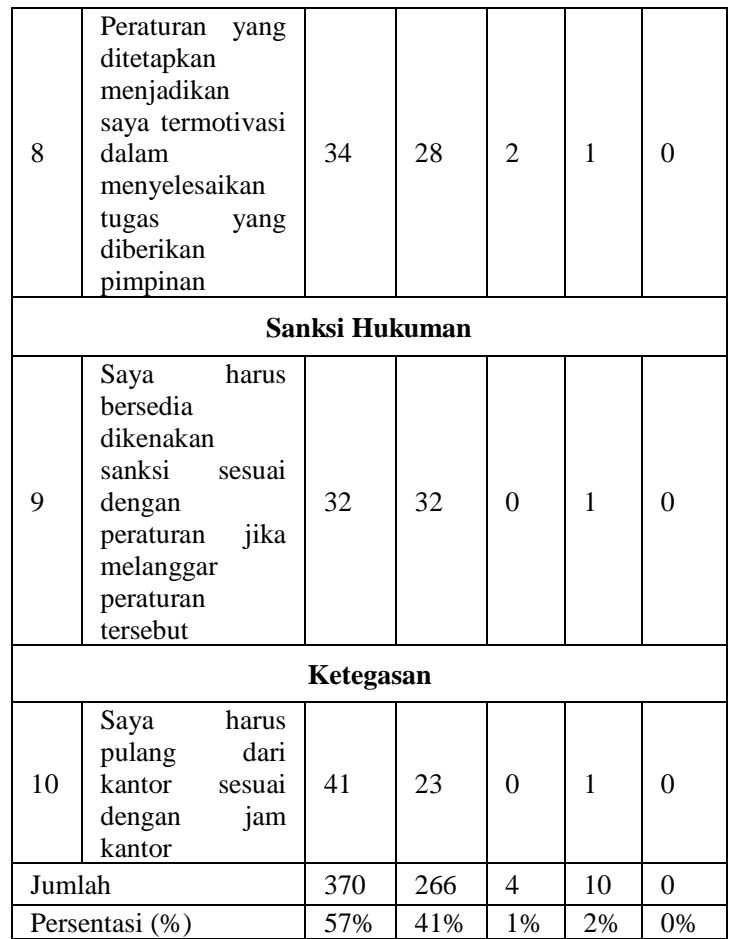

Sumber : Data primer

Dari tabel diatas dapat diketahui bahwa $57 \%$ responden menjawab sangat setuju, $41 \%$ responden menjawab setuju, $1 \%$ responden menjawab cukup setuju, $2 \%$ responden menjawab tidak setuju dan $0 \%$ responden menjawab sangat tidak setuju.

\section{Kinerja}

Tabel 4. 5

Jawaban Responden Kinerja (Y)

\begin{tabular}{|c|c|c|c|c|c|c|}
\hline \multirow{2}{*}{$\begin{array}{l}\mathbf{N} \\
\mathbf{0}\end{array}$} & \multirow{2}{*}{$\begin{array}{l}\text { Pernyataa } \\
\text { n }\end{array}$} & \multicolumn{5}{|c|}{ Skala Likert } \\
\hline & & SS & $\mathbf{S}$ & $\begin{array}{l}\text { C } \\
\text { S }\end{array}$ & $\begin{array}{l}\mathbf{T} \\
\mathbf{S}\end{array}$ & $\begin{array}{l}\text { ST } \\
\text { S }\end{array}$ \\
\hline \multicolumn{7}{|c|}{ Kompetensi Kepribadian } \\
\hline 1 & $\begin{array}{l}\text { Karyawan } \\
\text { dapat } \\
\text { bekerja } \\
\text { secara } \\
\text { kelompok } \\
\text { dengan } \\
\text { kompak }\end{array}$ & 36 & 28 & 1 & 0 & 0 \\
\hline 2 & $\begin{array}{l}\text { Karyawan } \\
\text { saling } \\
\text { membantu } \\
\text { dalam } \\
\text { kesulitan }\end{array}$ & 27 & 36 & 1 & 1 & 0 \\
\hline
\end{tabular}




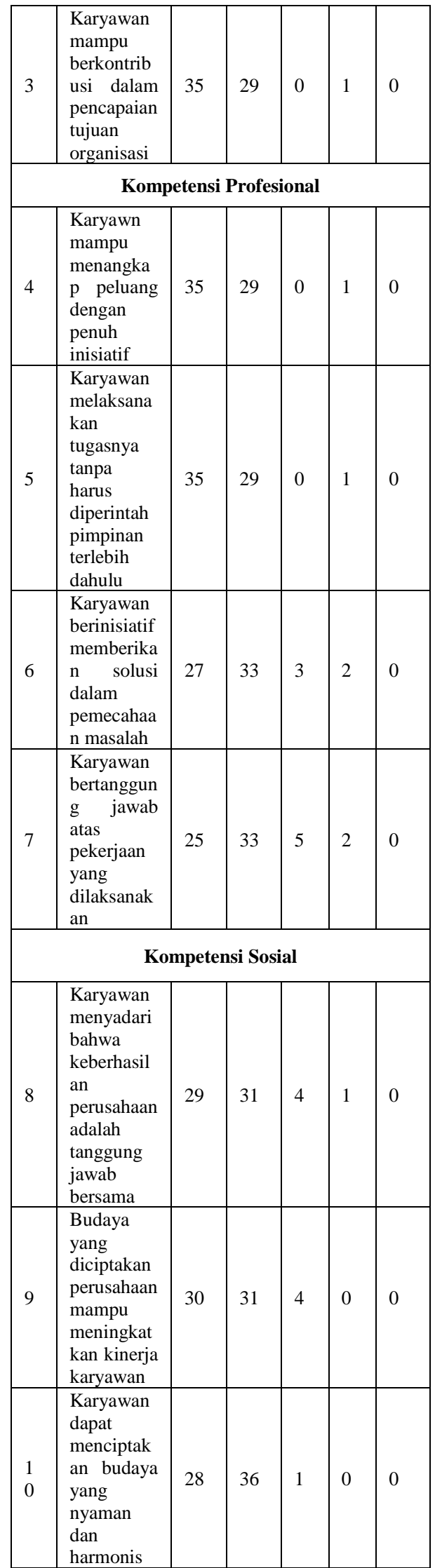

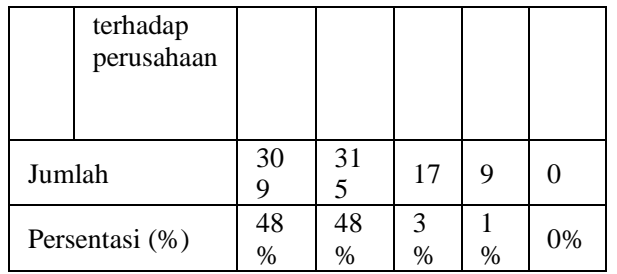

Sumber : Data primer

Dari tabel diatas dapat diketahui bahwa $48 \%$ responden menjawab sangat setuju, $48 \%$ responden menjawab setuju, 3\% responden menjawab cukup setuju, $1 \%$ responden menjawab tidak setuju dan $0 \%$ responden menjawab sangat tidak setuju.

\section{Uji Kualitas Data}

\section{Uji Validitas}

Pengujian validitas dilakukan untuk menguji instrumen penelitian yang telah disusun benar-benar akurat, sehingga mampu mengukur apa yang seharusnya di ukur (variabel kunci yang sedang di telilti). Validitas menunjukkan sejauh mana suatu alat ukur mampu mengukur suatu data apakah data tersebut valid atau tidak. Untuk mengelola uji validitas penulis menggunakan perhitungan statistic dengan software SPSS (Statistical Program For Social Science) version 22.0 for windows diperoleh $r$ hiutng lebih besar dari $r$ table dan nilai $r$ positif, maka butir pernyataan dikatakan valid, nilai $r$ table untuk 65 Responden dengan taraf kesalahan yang bias ditolerir ialah $5 \%$ ialah 0.244.

Kuesioner dibagi menjadi sepuluh (10) pernyataan dalam tiga (3) variabel yaitu variabel Gaya Kepemimpinan $\left(\mathrm{X}_{1}\right)$ dengan 10 kuesioner, variabel Disiplin Kerja $\left(\mathrm{X}_{2}\right)$ dengan 10 
kuesioner dan variabel Kinerja (Y) dengan 10 kuesioner. Jadi, kuesionernya terdiri dari total jumlah pernyataan 30 kuesioner. Ukuran validitas tiap butir-butir pernyataan dan pertanyaan dapat dilihat pada tabel-tabel di bawah ini :

Tabel 4. 6

Hasil Uji Validitas Variabel Gaya

\begin{tabular}{|c|c|c|c|c|}
\hline \multicolumn{5}{|c|}{ Kepemimpinan $\left(\mathrm{X}_{1}\right)$} \\
\hline $\begin{array}{l}\mathbf{N} \\
\mathbf{0}\end{array}$ & $\begin{array}{l}\text { Kuesio } \\
\text { ner }\end{array}$ & $\begin{array}{l}\mathrm{r}- \\
\text { tabel }\end{array}$ & $\begin{array}{l}\mathbf{r}- \\
\text { hitung }\end{array}$ & $\begin{array}{l}\text { Has } \\
\text { il } \\
\text { Uji }\end{array}$ \\
\hline 1 & $\begin{array}{l}\text { Pernyat } \\
\text { aan } \\
\text { butir } 1\end{array}$ & $\begin{array}{l}0,2 \\
44\end{array}$ & $\begin{array}{l}0,7 \\
30\end{array}$ & $\begin{array}{l}\text { Val } \\
\text { id }\end{array}$ \\
\hline 2 & $\begin{array}{l}\text { Pernyat } \\
\text { aan } \\
\text { butir } 2\end{array}$ & $\begin{array}{l}0,2 \\
44\end{array}$ & $\begin{array}{l}0,8 \\
36\end{array}$ & $\begin{array}{l}\text { Val } \\
\text { id }\end{array}$ \\
\hline 3 & $\begin{array}{l}\text { Pernyat } \\
\text { aan } \\
\text { butir } 3\end{array}$ & $\begin{array}{l}0,2 \\
44\end{array}$ & $\begin{array}{l}0,8 \\
47\end{array}$ & $\begin{array}{l}\text { Val } \\
\text { id }\end{array}$ \\
\hline 4 & $\begin{array}{l}\text { Pernyat } \\
\text { aan } \\
\text { butir } 4\end{array}$ & $\begin{array}{l}0,2 \\
44\end{array}$ & $\begin{array}{l}0,8 \\
78\end{array}$ & $\begin{array}{l}\text { Val } \\
\text { id }\end{array}$ \\
\hline 5 & $\begin{array}{l}\text { Pernyat } \\
\text { aan } \\
\text { butir } 5\end{array}$ & $\begin{array}{l}0,2 \\
44\end{array}$ & $\begin{array}{l}0,8 \\
44\end{array}$ & $\begin{array}{l}\text { Val } \\
\text { id }\end{array}$ \\
\hline 6 & $\begin{array}{l}\text { Pernyat } \\
\text { aan } \\
\text { butir } 6\end{array}$ & $\begin{array}{l}0,2 \\
44\end{array}$ & $\begin{array}{l}0,8 \\
52\end{array}$ & $\begin{array}{l}\text { Val } \\
\text { id }\end{array}$ \\
\hline 7 & $\begin{array}{l}\text { Pernyat } \\
\text { aan } \\
\text { butir } 7\end{array}$ & $\begin{array}{l}0,2 \\
44\end{array}$ & $\begin{array}{l}0,8 \\
85\end{array}$ & $\begin{array}{l}\text { Val } \\
\text { id }\end{array}$ \\
\hline 8 & $\begin{array}{l}\text { Pernyat } \\
\text { aan } \\
\text { butir } 8\end{array}$ & $\begin{array}{l}0,2 \\
44\end{array}$ & $\begin{array}{l}0,8 \\
51\end{array}$ & $\begin{array}{l}\text { Val } \\
\text { id }\end{array}$ \\
\hline 9 & $\begin{array}{l}\text { Pernyat } \\
\text { aan } \\
\text { butir } 9\end{array}$ & $\begin{array}{l}0,2 \\
44\end{array}$ & $\begin{array}{l}0,8 \\
40\end{array}$ & $\begin{array}{l}\text { Val } \\
\text { id }\end{array}$ \\
\hline $\begin{array}{l}1 \\
0\end{array}$ & $\begin{array}{l}\text { Pernyat } \\
\text { aan } \\
\text { butir } 10\end{array}$ & $\begin{array}{l}0,2 \\
44\end{array}$ & $\begin{array}{l}0,8 \\
02\end{array}$ & $\begin{array}{l}\text { Val } \\
\text { id }\end{array}$ \\
\hline
\end{tabular}

Sumber : Hasil olahan SPSS

Berdasarkan data pada tabel di atas, maka hasil penelitian menunjukkan bahwa dari pengujian tingkat validitas seluruh butir pernyataan yang ada pada kuesioner yang berdasarkan pada indikator variabel Gaya Kepemimpinan $\left(\mathrm{X}_{1}\right)$ dan mempunyai nilai $\mathrm{r}$ hitung lebih besar dari 0,244 sebanyak sepuluh (10) pernyataan. Berdasarkan hal tersebut maka dapat dikatakan bahwa kuesioner yang berisi pernyataan-pernyataan yang berdasarkan indikator variabel Disiplin Kerja $\left(\mathrm{X}_{1}\right)$ adalah valid atau memenuhi batas uji validitas 0,244 dan dapat dilanjutkan kepada pengujian regresi berikutnya.

Tabel 4.7

Hasil Uji Validitas Variabel Disiplin

\begin{tabular}{|c|c|c|c|c|}
\hline \multicolumn{5}{|c|}{ Kerja $\left(\mathbf{X}_{2}\right)$} \\
\hline $\begin{array}{l}\mathbf{N} \\
\mathbf{0}\end{array}$ & $\begin{array}{l}\text { Kuesio } \\
\text { ner }\end{array}$ & $\begin{array}{l}\text { r- } \\
\text { tabel }\end{array}$ & $\begin{array}{l}\mathbf{r}- \\
\text { hitung }\end{array}$ & $\begin{array}{l}\text { Has } \\
\text { il } \\
\text { Uji }\end{array}$ \\
\hline 1 & $\begin{array}{l}\text { Pernyat } \\
\text { aan } \\
\text { butir } 1\end{array}$ & $\begin{array}{l}0,2 \\
44\end{array}$ & $\begin{array}{l}0,8 \\
09\end{array}$ & $\begin{array}{l}\text { Val } \\
\text { id }\end{array}$ \\
\hline 2 & $\begin{array}{l}\text { Pernyat } \\
\text { aan } \\
\text { butir } 2\end{array}$ & $\begin{array}{l}0,2 \\
44\end{array}$ & $\begin{array}{l}0,8 \\
71\end{array}$ & $\begin{array}{l}\text { Val } \\
\text { id }\end{array}$ \\
\hline 3 & $\begin{array}{l}\text { Pernyat } \\
\text { aan } \\
\text { butir } 3\end{array}$ & $\begin{array}{l}0,2 \\
44\end{array}$ & $\begin{array}{l}0,7 \\
86\end{array}$ & $\begin{array}{l}\text { Val } \\
\text { id }\end{array}$ \\
\hline 4 & $\begin{array}{l}\text { Pernyat } \\
\text { aan } \\
\text { butir } 4\end{array}$ & $\begin{array}{l}0,2 \\
44\end{array}$ & $\begin{array}{l}0,8 \\
36\end{array}$ & $\begin{array}{l}\text { Val } \\
\text { id }\end{array}$ \\
\hline 5 & $\begin{array}{l}\text { Pernyat } \\
\text { aan } \\
\text { butir } 5\end{array}$ & $\begin{array}{l}0,2 \\
44\end{array}$ & $\begin{array}{l}0,8 \\
41\end{array}$ & $\begin{array}{l}\text { Val } \\
\text { id }\end{array}$ \\
\hline 6 & $\begin{array}{l}\text { Pernyat } \\
\text { aan } \\
\text { butir } 6\end{array}$ & $\begin{array}{l}0,2 \\
44\end{array}$ & $\begin{array}{l}0,8 \\
86\end{array}$ & $\begin{array}{l}\text { Val } \\
\text { id }\end{array}$ \\
\hline 7 & $\begin{array}{l}\text { Pernyat } \\
\text { aan } \\
\text { butir } 7\end{array}$ & $\begin{array}{l}0,2 \\
44\end{array}$ & $\begin{array}{l}0,7 \\
40\end{array}$ & $\begin{array}{l}\text { Val } \\
\text { id }\end{array}$ \\
\hline 8 & $\begin{array}{l}\text { Pernyat } \\
\text { aan } \\
\text { butir } 8\end{array}$ & $\begin{array}{l}0,2 \\
44\end{array}$ & $\begin{array}{l}0,7 \\
61\end{array}$ & $\begin{array}{l}\text { Val } \\
\text { id }\end{array}$ \\
\hline 9 & $\begin{array}{l}\text { Pernyat } \\
\text { aan } \\
\text { butir } 9\end{array}$ & $\begin{array}{l}0,2 \\
44\end{array}$ & $\begin{array}{l}0,8 \\
31\end{array}$ & $\begin{array}{l}\text { Val } \\
\text { id }\end{array}$ \\
\hline $\begin{array}{l}1 \\
0\end{array}$ & $\begin{array}{l}\text { Penyata } \\
\text { an butir } \\
10\end{array}$ & $\begin{array}{l}0,2 \\
44\end{array}$ & $\begin{array}{l}0,7 \\
16\end{array}$ & $\begin{array}{l}\text { Val } \\
\text { id }\end{array}$ \\
\hline
\end{tabular}

Sumber : Hasil olahan SPSS

Hasil olah data, menghasilkan bahwa seluruh butir pernyataan variabel Disiplin Kerja adalah valid. Hal ini dapat dilihat bahwa nilai korelasi 10 item pernyataan lebih besar dari 0,244. Oleh karenanya data ini dapat dilanjutkan pada analisis regresi linear berganda. 
Tabel 4. 8

Hasil Uji Validitas Variabel Kinerja (Y)

\begin{tabular}{|c|c|c|c|c|}
\hline $\begin{array}{l}\mathbf{N} \\
\mathbf{0}\end{array}$ & $\begin{array}{l}\text { Kuesio } \\
\text { ner }\end{array}$ & $\begin{array}{l}\mathbf{r}- \\
\text { hitung }\end{array}$ & $\begin{array}{l}\mathbf{r}- \\
\text { hitung }\end{array}$ & $\begin{array}{l}\text { Has } \\
\text { il } \\
\text { Uji }\end{array}$ \\
\hline 1 & $\begin{array}{l}\text { Pernyat } \\
\text { aan } \\
\text { butir } 1\end{array}$ & $\begin{array}{l}0,2 \\
44\end{array}$ & $\begin{array}{l}0,8 \\
76\end{array}$ & $\begin{array}{l}\text { Val } \\
\text { id }\end{array}$ \\
\hline 2 & $\begin{array}{l}\text { Pernyat } \\
\text { aan } \\
\text { butir } 2\end{array}$ & $\begin{array}{l}0,2 \\
44\end{array}$ & $\begin{array}{l}0,7 \\
88\end{array}$ & $\begin{array}{l}\text { Val } \\
\text { id }\end{array}$ \\
\hline 3 & $\begin{array}{l}\text { Pernyat } \\
\text { aan } \\
\text { butir } 3\end{array}$ & $\begin{array}{l}0,2 \\
44\end{array}$ & $\begin{array}{l}0,8 \\
58\end{array}$ & $\begin{array}{l}\text { Val } \\
\text { id }\end{array}$ \\
\hline 4 & $\begin{array}{l}\text { Pernyat } \\
\text { aan } \\
\text { butir } 4\end{array}$ & $\begin{array}{l}0,2 \\
44\end{array}$ & $\begin{array}{l}0,8 \\
73\end{array}$ & $\begin{array}{l}\text { Val } \\
\text { id }\end{array}$ \\
\hline 5 & $\begin{array}{l}\text { Pernyat } \\
\text { aan } \\
\text { butir } 5\end{array}$ & $\begin{array}{l}0,2 \\
44\end{array}$ & $\begin{array}{l}0,9 \\
18\end{array}$ & $\begin{array}{l}\text { Val } \\
\text { id }\end{array}$ \\
\hline 6 & $\begin{array}{l}\text { Pernyat } \\
\text { aan } \\
\text { butir } 6\end{array}$ & $\begin{array}{l}0,2 \\
44\end{array}$ & $\begin{array}{l}0,9 \\
15\end{array}$ & $\begin{array}{l}\text { Val } \\
\text { id }\end{array}$ \\
\hline 7 & $\begin{array}{l}\text { Pernyat } \\
\text { aan } \\
\text { butir } 7\end{array}$ & $\begin{array}{l}0,2 \\
44\end{array}$ & $\begin{array}{l}0,8 \\
66\end{array}$ & $\begin{array}{l}\text { Val } \\
\text { id }\end{array}$ \\
\hline 8 & $\begin{array}{l}\text { Pernyat } \\
\text { aan } \\
\text { butir } 8\end{array}$ & $\begin{array}{l}0,2 \\
44\end{array}$ & $\begin{array}{l}0,9 \\
11\end{array}$ & $\begin{array}{l}\text { Val } \\
\text { id }\end{array}$ \\
\hline 9 & $\begin{array}{l}\text { Pernyat } \\
\text { aan } \\
\text { butir } 9\end{array}$ & $\begin{array}{l}0,2 \\
44\end{array}$ & $\begin{array}{l}0,8 \\
84\end{array}$ & $\begin{array}{l}\text { Val } \\
\text { id }\end{array}$ \\
\hline $\begin{array}{l}1 \\
0\end{array}$ & $\begin{array}{l}\text { Pernyat } \\
\text { aan } \\
\text { butir } 10\end{array}$ & $\begin{array}{l}0,2 \\
44\end{array}$ & $\begin{array}{l}0,8 \\
23\end{array}$ & $\begin{array}{l}\text { Val } \\
\text { id }\end{array}$ \\
\hline
\end{tabular}

Sumber : Hasil olahan SPSS

Berdasarkan hasil pengolahan uji validitas dalam pernyataan pada kuesioner varibel Kinerja (Y) pada tabel 4. 8 di atas, seluruh kuesioner adalah valid. Di mana setiap butir pernyataan memiliki nilai korelasi lebih besar dari 0,244. Dengan kata lain data ini dapat digunakan untuk analisis regresi.

\section{Uji Reliabilitas}

Reliabilitas merupakan serangkaian pengukuran atau serangkaian alat ukur yang memiliki konsistensi bila pengukuran yang dilakukan dengan alat ukur itu dilakukan secara berulang, (Sugiyono, 2015).
Untuk mengelola uji reliabilitas digunakan software SPSS (Statistical Program For Social Science) version 22.0 for windows, jika nilai alpha cronbach > $\mathrm{r}$ table dan nilai $r$ positif maka butir pernyataan dikatakan reliable, adapun nilai $\mathrm{r}$ table (two tailed) untuk 65 responden dengan taraf kesalahan 5\%, maka 0,244.

Tabel 4.9

Hasil Uji Reliabilitas Variabel Penelitian

\begin{tabular}{|l|l|l|l|}
\hline Variabel & $\begin{array}{l}\text { Batas } \\
\text { Reabilitas }\end{array}$ & $\begin{array}{l}\text { Alpha } \\
\text { Chronbach's }\end{array}$ & Keterangan \\
\hline Kinerja (Y) & 0,244 & 0,964 & Reliabel \\
\hline $\begin{array}{l}\text { Gaya } \\
\text { Kepemimpinan } \\
\left(\mathrm{X}_{1}\right)\end{array}$ & 0,244 & 0,952 & Reliabel \\
\hline $\begin{array}{l}\text { Disiplin Kerja } \\
\left(\mathrm{X}_{2}\right)\end{array}$ & 0,244 & 0,940 & Reliabel \\
\hline
\end{tabular}

Sumber : Hasil olahan SPSS

Berdasarkan tabel di atas dapat dilihat bahwa hasil perhitungan Uji reabilitas melalui program komputer SPSS 24.0 menunjukkan bahwa jumlah chronbach alpha variabel Kinerja (Y) lebih besar nilainya sebesar 0,964 dari pada batas reabilitas 0,244 hal ini menunjukkan bahwa variabel kinerja reliabel, Gaya Kepemimpinan $\left(\mathrm{X}_{1}\right)$, lebih besar nilainya sebesar 0,952 dari pada batas reabilitas 0,244 maka dapat dikatakan bahwa variabel gaya kepemimpinan reliabel dan variabel Disiplin Kerja $\left(\mathrm{X}_{2}\right)$ lebih besar nilainya sebesar 0,940 dari pada batas reliabilitas 0,244 maka dapat dikatakan bahwa variabel disiplin kerja reliabel. Berdasarkan pada pendapat tersebut di atas maka dapat diartikan bahwa hasil jawaban responden terhadap kuesioner yang berisi pernyataan dan variabelvariabel dalam penelitian ini reliabel atau memenuhi standar uji 
reliabilitas maka penelitian ini dapat dilanjutkan pada pengujian selanjutnya.

\section{E. Uji Asumsi Klasik}

1. Normalitas

Hasil pengujian normalitas data pada variabel Gaya Kepemimpinan dan Disiplin Kerja terhadap Kinerja kerja karyawan di peroleh hasil sebagai berikut :

\section{Tabel 4.10}

Uji normalitas dengan metode

Kolmogorov-Smirnov

One-Sample Kolmogorov-Smirnov Test

\begin{tabular}{|ll|l|l|l|}
\hline & & $\begin{array}{l}\text { Gaya } \\
\text { Kepemimpina } \\
\mathrm{n}\end{array}$ & $\begin{array}{l}\text { Disipli } \\
\text { n Kerja }\end{array}$ & $\begin{array}{l}\text { Kinerj } \\
\mathrm{a}\end{array}$ \\
\hline $\mathrm{N}$ & 65 & 65 & 65 \\
Normal & Mean & 45.32 & 44.42 & 44.22 \\
Parameters & Std. \\
& & 4.975 & 4.915 & 5.340 \\
& Deviatio & & & \\
& $\mathrm{n}$ & & .128 & .145 \\
Most & Absolute & .174 & .128 & .139 \\
Extreme & Positive & .174 & -.123 & -.145 \\
Differences & Negative & -.155 & 1.031 & 1.172 \\
Kolmogorov-Smirnov & 1.400 & & \\
Z & & & .238 & .128 \\
\hline
\end{tabular}

a. Test distribution is Normal.

b. Calculated from data.

Sumber : Hasil olahan SPSS

Berdasarkan hasil olah data, diketahui bahwa data variabel Gaya Kepemimpinan memiliki nilai Asymp. Sig 0.80 lebih besar dari 0.05. kemudian variabel disiplin kerja memiliki nilai Asymp. Sig lebih besar dari 0.05 dan variabel kinerja memiliki nilai Asymp. Sig lebih besar dari 0.05. Hasil ini menyimpulkan bahwa data adalah normal. Suatu data dikatakan normal apabila memiliki nilai Asymp. Sig lebih besar dari 0.05 atau disebut dengan p-value.

Secara umum uji normalitas digunakan untuk melihat variasi nilai dan kemungkinan bahwa nilai tersebut dapat mendekati pada nilai populasi secara keseluruhan. Uji normalitas ini dapat mengetahui kemungkinan sampel yang diambil apakah dapat menggambarkan atau mewakili keseluruhan populasi. Namun perlu di ingat pula bahwa uji normalitas bukan hal yang menentukan keberlanjutan penelitian tetapi, hanya ingin melihat seberapa besar kemampuan sampel yang diambil dapat mewakili populasi karena besar atau kecilnya sampel yang diambil sangatlah mempengaruhi terhadap nilai normalitas.

2. Heteroskedastisitas

Pengujian heteroskedasitas bertujuan untuk menguji apakah dalam suatu model regresi terjadi ketidaksamaan varians residual dari suatu pengamatan yang lain. Model regresi yang baik adalah regresi yang tidak terdapat heteroskedatisitas, yaitu model regresi yang memiliki persamaan variance residual suatu periode pengamatan dengan periode pengamatan yang lain. Uji heteroskedastisitas ini dapat dilihat pada gambar 4.2 di bawah ini :

Scatterplot

Dependent variable: Kinerja

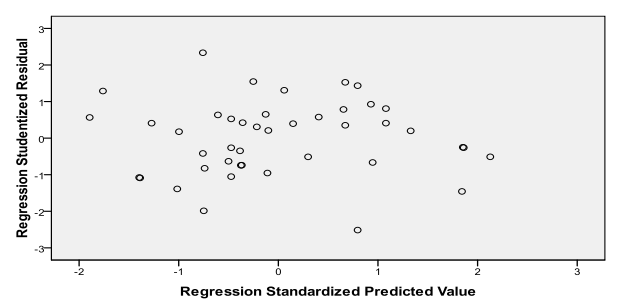

Gambar 4. 2 Scatterplot

Berdasarkan gambar hasil pengolahan SPSS 22.0 (Scatterplot) di atas maka dapat di artikan bahwa data yang di peroleh dengan menggunakan kuesioner merupakan 
data murni dari responden. Hal ini dapat dilihat pada gambar di atas titik residual data tidak memiliki kesamaan antara responden yang satu dengan responden yang lainnya, sehingga data yang di peroleh dari penyebaran kuesioner telah memenuhi uji hesteroskedastisitas.

\section{Multikolinearitas}

Pengujian multikolinearitas bertujuan untuk menguji pengaruh dari variabel independen yaitu Gaya Kepemimpinan (X1) dan Disiplin Kerja (X2) terhadap variabel dependen Kinerja (Y) disajikan melalui tabel 4.11 Di bawah ini.

Tabel 4. 11

Uji Multikolinearitas

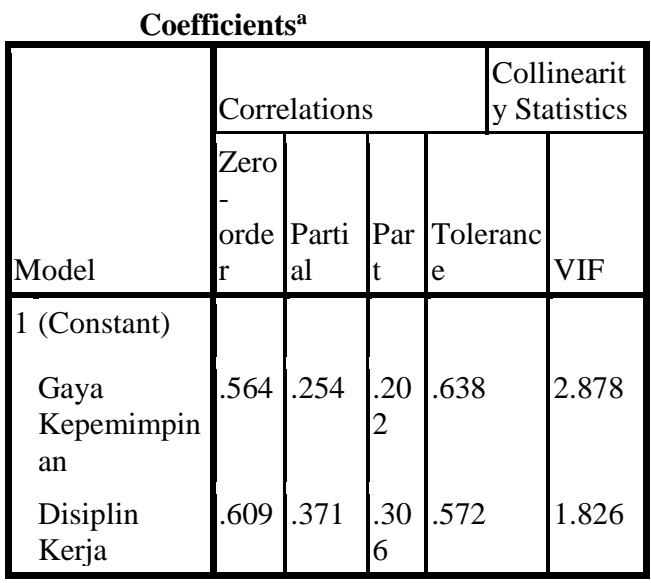

a. Dependent Variable: Kinerja

Sumber hasil olahan SPSS

Berdasarkan data hasil

Pengujian menggunakan Nilai

Tolerance da VIF menunjukkan bahwa nilai variabel gaya kepemimpinan $\left(\mathrm{X}_{1}\right)$ memiliki nilai tolerance 0.638 lebih kecil dari 1.00 dan nilai VIF 2.878 lebih kecil dari 10 maka dapat dikatakan tidak terjadi Multikolinearitas. Begitupula variabel disiplin kerja $\left(\mathrm{X}_{2}\right)$ memiliki nilai tolerancenya 0,572 lebih kecil dari 1.00 dan nilai VIF 1.826 lebih kecil dari 10 maka dapat dikatakan tidak terjadi Multikolinearitas.

\section{F. Pembahasan Penelitian}

1. Uji Parsial (uji t)

Menurut Bambang Tri Cahyono (2005:99) menyatakan uji parsial (uji t) digunakan untuk mengetahui apakah estimator terhadap parameter berbeda secara signifikan dari nol. Untuk pengujian pengaruh antara variabel Gaya Kepemimpinan $\left(\mathrm{X}_{1}\right)$ dan Disiplin Kerja $\left(\mathrm{X}_{2}\right)$ masing-masing terhadap Kinerja (Y) dapat dilakukan uji statistik t (uji parsial). Sebagai pembanding untuk melihat pengaruh signifikan, maka digunakan kriteria taraf signifikan sebesar $5 \%(0,05)$ dan membandingkan t-hitung dengan t-tabel dengan kriteria sebagai berikut :

a. Jika t-hitung $<$ t-tabel berharti $\mathrm{HO}$ diterima dan $\mathrm{Ha}$ di tolak

b. Jika t-hitung > t-tabel berarti $\mathrm{HO}$ ditolak dan $\mathrm{Ha}$ diterima

Adapun ketentuan t-tabel diperoleh dengan cara membandingkan jumlah sampel dengan taraf signifikan (65 sampel : $0,05)$ maka diperoleh t-tabel sebesar

$$
\text { dk }=\mathbf{n}-\mathbf{k}-1
$$

dimana $n$ adalah jumlah responden dan $k$ adalah jumlah variabel yang diteliti, kemudian dengan membandingkan $\mathrm{t}$ hitung dengan $\mathrm{t}$ tabel dengan kriteria:

$>\quad$ Jika $\mathrm{t}_{\text {hitung }} \geq \mathrm{t}_{\text {tabel, }}(a ; d k)$, berarti $\mathrm{H}_{01}$ ditolak dan $\mathrm{H}_{\mathrm{a} 1}$ diterima. 
$>\quad$ Jika $\mathrm{t}_{\text {hitung }} \leq \mathrm{t}_{\text {tabel, }},(a ; d k)$, berarti $\mathrm{H}_{02}$ diterima dan $\mathrm{H}_{\mathrm{a} 2}$ ditolak

Dimana drajat kebebasan $(d k)$ adalah:

$$
\begin{aligned}
\mathrm{dk} \quad & \mathrm{n}-\mathrm{k}-1 \\
& =65-3-1 \\
& =61 \\
\mathrm{t}_{\text {tabel }}= & \mathrm{t} \\
& (a ; d k) \\
& =(0,05 ; 61) \\
& =2,000
\end{aligned}
$$

Adapun hasil pengolahan menggunakan program SPSS 22.0, pengaruh variabel Gaya Kepemimpinan $\left(\mathrm{X}_{1}\right)$ dan Disiplin

\begin{tabular}{|c|c|c|c|c|c|}
\hline \multirow[b]{2}{*}{ Model } & \multicolumn{2}{|c|}{$\begin{array}{l}\text { Unstandardi } \\
\text { zed } \\
\text { Coefficients }\end{array}$} & \multirow{2}{*}{$\begin{array}{l}\begin{array}{l}\text { Standardiz } \\
\text { ed } \\
\text { Coefficien } \\
\text { ts }\end{array} \\
\text { Beta }\end{array}$} & \multirow[b]{2}{*}{$\mathrm{T}$} & \\
\hline & B & $\begin{array}{l}\text { Std. } \\
\text { Error }\end{array}$ & & & Sig \\
\hline 1 (Constant) & $\begin{array}{l}1.87 \\
3\end{array}$ & 3.281 & & .571 & $\begin{array}{l}.57 \\
0\end{array}$ \\
\hline $\begin{array}{l}\text { Gaya } \\
\text { Kepemimpi } \\
\text { nan }\end{array}$ & .391 & .171 & .364 & $\begin{array}{l}2.28 \\
5\end{array}$ & $\begin{array}{l}.02 \\
6\end{array}$ \\
\hline $\begin{array}{l}\text { Disiplin } \\
\text { Kerja }\end{array}$ & .555 & .173 & .510 & $\begin{array}{l}3.20 \\
2\end{array}$ & $\begin{array}{l}.00 \\
2\end{array}$ \\
\hline
\end{tabular}
Kerja $\left(\mathrm{X}_{2}\right)$ terhadap variabel Kinerja (Y) sebagai berikut :

Tabel 4. 12

Analisis Regresi Linear Berganda Coefficients $^{\mathrm{a}}$

a. Dependent Variable: Kinerja

Sumber : Data diolah SPSS

Berdasarkan output data tabel di atas dapat di peroleh hasil sebagai berikut :

a) Persamaan Regresi $\mathrm{Y}=1.873+$ $0.364\left(\mathrm{X}_{1}\right)+0.510\left(\mathrm{X}_{2}\right)$

- Konstanta sebesar 1.873, menjelaskan meskipun tidak ada variabel Gaya Kepemimpinan dan Disiplin yang mempengaruhi kinerja karyawan tetap memiliki nilai kinerja sebesar 1.873 .
- Variabel Gaya Kepemimpinan (X1) terbukti berpengaruh terhadap Kinerja sebesar 0.364.

- Variabel Disiplin Kerja terbukti berpengaruh terhadap Kinerja sebesar 0.510

b) Membandingkan $T_{\text {hitung }}$ lebih besar dari tabel

- Variabel Gaya Kepemimpinan memiliki nilai $\mathrm{T}_{\text {hitung }}$ lebih besar dari $t_{\text {tabel }}$ yaitu $2.285>$ 2,000. ini menjelaskan bahwa pengaruh Gaya Kepemimpinan terhadap Kinerja adalah positif, yang artinya jika variabel Gaya Kepemimpinan naik, maka Kinerja karyawan naik.

- Variabel Disiplin Kerja memiliki nilai $T_{\text {hitung }}$ lebih besar dari tabel yaitu 3.202 > 2,000. ini menjelaskan bahwa pengaruh Disiplin Kerja terhadap Kinerjaadalah positif, yang artinya jika variabel Disiplin Kerjanaik, maka Kinerja kerja karyawan naik.

c) Membandingkan Nilai signifikansi 0.05

- Variabel Gaya Kepemimpinan memiliki nilai sig lebih kecil dari 0.05 yaitu $0.026>0.05$. ini menjelaskan bahwa pengaruh Gaya Kepemimpinan terhadap Kinerja adalah signifikan, yang artinya Gaya Kepemimpinan secara nyata dapat mempengaruhi Kinerja seseorang dalam bekerja.

- Variabel Disiplin Kerja memiliki nilai sig lebih kecil dari 0.05 yaitu $0.002>0.05$. ini menjelaskan bahwa pengaruh Disiplin Kerja terhadap Kinerja adalah signifikan, yang artinya 
Disiplin Kerja secara jelas dapat mempengaruhi Kinerja seseorang dalam bekerja.

2. Uji simultan (Uji f)

Menurut Ghozali ( 2005:98) menyatakan bahwa uji simultan atau uji f dilakukan untuk mengetahui pengaruh variabel-variabel indepen terhadap variabel dependent. Hasil pengujian simultan (uji f) ini juga digunakan untuk melihat secara simultan apakah variabel independen yaitu variabel Gaya Kepemimpinan (X1) mempengaruhi dan variabel Disiplin Kerja (X2) secara bersama-sama berpengaruh terhadap variabel dependen yaitu Kinerja (Y). Sebagai pembanding untuk melihat pengaruh signifikan, maka digunakan kriteria taraf signifikan sebesar $5 \%(0,05)$ dan membandingkan $\mathrm{F}$ hitung dengan $\mathrm{F}$ tabel. Kriteria F hitung adalah sebagai berikut :

1) Jika $F$ hitung $<F$ tabel berarti H0 diterima dan Ha ditolak.

2) Jika $F$ hitung $>F$ tabel berarti H0 ditolak dan Ha diterima.

Adapun ketentuan F tabel di peroleh dengan cara membandingkan jumlah variabel independen dengan taraf signifikan (2 variabel : 0,05 ), maka diperoleh $\mathrm{F}$ tabel sebesar :

$$
\begin{aligned}
& \mathrm{dk}=\mathrm{n}-\mathrm{k}-1 \\
& =65-3-1 \\
& =61 \\
& \mathrm{~F}_{\text {tabel }}=\mathrm{F}(a ; d k) \\
& =(0,05 ; 62) \\
& =2,76 \\
& \mathrm{~F}_{\text {hitung }} \text { dan } \mathrm{F}_{\text {tabel }} \\
& \mathrm{F}_{\text {hitung adalah } 84.470 \text { (lihat pada tabel }} \\
& \quad \text { anova) } \\
& \mathrm{F}_{\text {tabel dapat dicari pada tabel statistik }} \\
& \text { pada signifikansi } 0,05 \text { : }
\end{aligned}
$$

df $1=\mathrm{k}-1$ atau 3-1 = 2, dan

df $2=\mathrm{k}-2$ atau $3-1=2$ (k adalah jumlah variabel), di dapat $F$ tabel adalah 2,76.

1) Ho : $\beta=0$

Tidak ada pengaruh Gaya Kepemimpinan dan Disiplin Kerja terhadap Kinerja karyawan secara simultan.

2) $\mathrm{Ha}: \beta \neq 0$

Adanya pengaruh Gaya Kepemimpinan dan Disiplin Kerja terhadap Kinerja karyawan secara simultan.

Dari hasil pengolahan data terhadap statistic F maka diperoleh tabel sebagai berikut :

Tabel 4. 13

Uji Simultan (F)

ANOVA $^{\mathbf{b}}$
\begin{tabular}{|l|l|l|l|l|l|}
\hline Model & $\begin{array}{l}\text { Sum of } \\
\text { Squares }\end{array}$ & df & $\begin{array}{l}\text { Mean } \\
\text { Square }\end{array}$ & F & Sig. \\
\hline 1 Regression & 1335.035 & 2 & 667.518 & 84.470 & $.000^{\mathrm{a}}$ \\
Residual & 489.949 & 62 & 7.902 & & \\
Total & 1824.985 & 64 & & & \\
\hline
\end{tabular}

a. Predictors: (Constant), Gaya Kepemimpinan, Disiplin Kerja

b. Dependent Variable: Kinerja.

Sumber : Data di olah SPSS

Hasil tabel 4.13 di atas menyimpulkan bahwa nilai dari $\mathrm{F}$ hitung sebesar 84.470 lebih besar dari pada $F$ tabel sebesar 2,76 atau persamaannya $84.470>2,76$ sedangkan $\mathrm{p}$ - valuenya lebih kecil dari 0,05 atau sebesar 0,000 dengan persamaan 0,05 >0,00 maka sesuai dengan pengukuran standar uji simultan yaitu $\mathrm{Ha}$ diterima dan $\mathrm{Ho}$ ditolak. Hal tersebut berarti bahwa variabel Gaya Kepemimpinan dan variabel Disiplin Kerja secara simultan bersama-sama memiliki 
pengaruh positif dan signifikan terhadap variabel Kinerja.

3. Uji Koefisien Determinasi

Menurut Ghozali (2005:102) menyatakan bahwa koefisien determinasi $\left(\mathrm{R}^{2}\right)$ bertujuan untuk mengetahui seberapa besar kemampuan variabel independen menjelaskan variabel dependen. Dalam output SPSS, koefisien determinasi terletak pada tabel Model Summary ${ }^{b}$ dan tertulis adjusted $R$ square.

Berdasarkan definisi uji determinasi tersebut maka, penelitian ini memperoleh tabel sebagai berikut

Tabel 4.14

Hasil Uji Determinasi

Model Summary

\begin{tabular}{|l|l|l|l|l|}
\hline Model & $R$ & $\begin{array}{l}\mathrm{R} \\
\text { Square }\end{array}$ & $\begin{array}{l}\text { Adjusted R } \\
\text { Square }\end{array}$ & $\begin{array}{l}\text { Std. Error of } \\
\text { the Estimate }\end{array}$ \\
\hline 1 & $.855^{\mathrm{a}}$ & .732 & .723 & 2.811 \\
\hline
\end{tabular}

a. Predictors: (Constant), Gaya Kepemimpinan , Disiplin Kerja

Sumber : Data di olah SPSS

Berdasarkan data hasil uji determinasi dari tabel 4.14 di atas maka dapat di tarik kesimpulan sebagai berikut :

1) Hasil uji determinasi pada tabel 4.14 di atas mengartikan bahwa nilai Adjusted $\mathrm{R}^{2}$ pada uji determinasi variabel Gaya Kepemimpinan dan Disiplin Kerja terhadap Kinerja karyawan sebesar 0,723. Mengingat bahwa nilai tersebut tidak mencapai 1 maka Sesuai dengan pendapat Ghozali (2005:102) menyatakan jika nilai $\mathrm{R}^{2}$ berkisar antara 0 sampai dengan 1, berarti semakin kuat kemampuan variabel independen dapat menjelaskan fluktuasi variabel dependen. Maka berarti jelas bahwa variabel Gaya
Kepemimpinan dan Disiplin Kerja dapat menjelaskan fluktuasi variabel Kinerja.

2) Hasil uji determinasi pada tabel 4.14 di atas juga menyimpulkan bahwa koefisien determinasi memiliki nilai sebesar 0,723 yang berarti bahwa pengaruh Gaya Kepemimpinan dan Disiplin Kerja terhadap Kinerja karyawan memiliki tingkat persentasi sebesar 72,3\%. Hal ini menyatakan bahwa jelas jika perusahaan ingin lebih meningkatkan Kinerja karyawan maka dapat menggunakan indikator-indikator pada Gaya Kepemimpinan dan Disiplin Kerja untuk lebih ditingkatkan lagi sehingga Kinerja karyawan pun akan meningkat. Variabelvariabel lain yang dapat digunakan perusahaan dalam upaya untuk meningkatkan Kinerja karyawan memiliki tingkat presentasi sebesar $27,7 \%$. Pendapat tersebut sesuai dengan pendapat yang dikemukakan oleh Bambang Tri Cahyono ( 2005:99) yang menyatakan bahwa koefisien determinasi $\left(\mathrm{R}^{2}\right)$ digunakan untuk melihat berapa persen dari variasi variabel dependen dapat diterangkan oleh variasi dari variabel independen.

\section{KESIMPULAN, DAN SARAN \\ Kesimpulan}

Berdasarkan hasil penelitian yang telah dilakukan mengenai pengaruh Gaya Kepemimpinan dan Disiplin Kerja terhadap Kinerja karyawan, maka dapat di tarik kesimpulan sebagai berikut :

1. Berdasarkan hasil analisis regresi variabel Gaya 
Kepemimpinan (X1) terbukti berpengaruh positif dan signifikan terhadap kinerja sebesar 0.364. Hasil ini menjawab rumusan masalah satu dan Ha diterima serta Ho ditolak.

2. Berdasarkan hasil analisis regresi variabel Disiplin Kerja terbukti berpengaruh positif dan signifikan terhadap Kinerja karyawan sebesar 0.510. Hasil ini menjawab rumusan masalah dua dan Ha diterima serta Ho ditolak.

3. Hasil analisis simultan membuktikan Gaya Kepemimpinan dan Disiplin Kerja terbukti secara bersama-sama berpengaruh positif dan signifikan terhadap Kinerja dengan nilai F hitung sebesar 84.470 lebih besar dari pada $F$ tabel sebesar 2,76 atau persamaannya $84.470>2,76$ sedangkan $\mathrm{p}$ - valuenya lebih kecil dari 0,05 atau sebesar 0,000 dengan persamaan 0,05 $>0,00$ dengan nilai koefisien determinasi sebesar $72,3 \%$ maka sesuai dengan pengukuran standar uji simultan yaitu $\mathrm{Ha}$ diterima dan Ho ditolak.

\section{Saran}

Berdasarkan kesimpulan yang telah dilakukan maka saran yang dapat diberikan dalam penelitian ini yaitu:

1. Bagi Perusahaan

a. Hendaknya perusahaan dalam meningkatkan kinerja karyawan lebih menitikberatkan pada gaya kepemimpinan,

berdasarkan kuesioner gaya kepemimpinan dapat meningkatkan kinerja karyawan yang lebih baik lagi.

b. Hendaknya disiplin kerja lebih di tingkatkan lagi untuk mencapai tujuan perusahaan yaitu mendapatkan profit yang setinggi-tingginya dan menjaga kepercayaan konsumen.

c. Hendaknya karyawan memberikan inisiatif membemberikan solusi dalam pemecahan masalah di dalam perusahaan

d. Hendaknya karyawan lebih bertanggung jawab atas pekerjaan yang di bebankan kepada nya.

2. Bagi Penelitian Selanjutnya Hasil Uji $\mathrm{R}^{2}$ menunjukkan masih ada variabel-variabel lain yang harus diperhatikan dalam penelitian ini. Penelitianpenelitian lebih lanjut, hendaknya menambah variabel lain yang dapat mempengaruhi kinerja karyawan, karena dengan semakin baik kinerja dari karyawan maka akan berpengaruh baik juga bagi perusahaan.

\section{DAFTAR PUSTAKA}

A.A. Anwar Prabu Mangkunegara (2012), Manajamen Sumber Daya Manusia Perusahaan, PT Remaja Rosdakarya, Bandung.

Arikunto, Suharsimi (2006), Prosedur Penelitian Suatu 
Pendekatan Praktek, Rineka Cipta. Jakarta.

Aritonang, Keke.T. (2015), Kompensasi Kerja, Disiplin Kerja Guru Dan Kinerja Guru SMP Kristen BPK PENABUR. Jurnal Pendidikan Penabur. Jakarta.

Burhanuddin (2014), Manajemen Sumber Daya Manusia. Erlangga. Jakarta.

Dessler (2010), Manajemen Sumber Daya Manusia. Indeks. Jakarta.

Gomes (2005), Organisasi dan Manajemen- PerilakuStruktur-Proses, terjemahan Djoerban Wahid, Penerbit Erlangga, Jakarta.

Guritno, Bambang dan Waridin (2015),Pengaruh Persepsi Karyawan Mengenai Perilaku Kepemimpinan, Kepuasan Kerja Dan Motivasi Terhadap Kinerja.JRBI. Jakarta.

Handoko T. Hani, (2012), Manajemen Personalia dan Sumber Daya Manusia, edisi kedua, BPFE, Yogyakarta

Hasibuan, Malayu SP (2012), Manajemen Sumber Daya Manusia, Edisi Revisi, Penerbit Bumi Aksara, Jakarta.

Henry Simamora (2005), Manajemen Sumber Daya Manusia, STIE YKPN Bandung.
Kerebet, Widjayakusuma (2000), Manajemen Sumber Daya Manusia, Bumi Aksara. Jakarta.

Marwansyah (2012), Manajemen Sumber Daya Manusia, Alfabeta. Jakarta.

Nanang, Fatah (2012), Landasan Manajemen Pendidikan. Rosdakarya. Bandung.

Nawawi, Hadari (2012), Manajemen Sumber Daya Manusia Untuk Bisnis yang Kompetitif,cetakan keempat, Gadjah Mada University Press, Yogyakarta.

Noe, Gerhart, Wright (2006), Manajemen Sumber Daya Manusia, Salemba Empat. Jakarta.

Riduwan, (2009), Metode dan tehnik menyusun tesis, Alfabeta, Bandung.

Rivai, Veithzal. (2003), Manajemen Sumber Daya Manusia Untuk Perusahaan, PT. Rajagrafindo Persada. Jakarta

Robbins, Stephen. P. (2006), Perilaku organisasi. Edisi Bahasa Indonesia. PT Indeks Kelompok GRAMEDIA. Jakarta.

Sadili Samsudin (2005), Manajemen Sumber Daya Manusia, Pustaka Setia, Bandung.

Setiyawan, Budi dan Waridin. (2016). 
Pengaruh Disiplin Kerja

Karyawan Dan Budaya

Organisasi Terhadap Kinerja

Di Divisi Radiologi RSUP

Dokter Kariadi Semarang. JRBI. Jakarta.

Siagian, Sondong. P. (2002), Kiat

Meningkatkan Produktivitas

Kerja, PT Rineka Cipta. Jakarta.

Sinambela, Poltak (2012), Manajemen Sumber Daya Manusia, Bumi Aksara. Jakarta.

Sudjana (2012), Manajemen Praktis

Sumber Daya Manusia.

Mandar Maju. Bandung.

Sugiyono (2011), Metode Penelitian Administrasi : dilengkapi dengan Metode $R \& D$, , Alfabeta, Bandung.

Suharsimi Arikunto (2006), Manajemen Penelitian, Edisi Revisi, Cetakan Ketujuh, Rineka Cipta, Jakarta.

Suherman, Asep (2012), Sistem Sumber Daya Manusia, Academia. Jakarta.

Sunyoto, Danang (2013), Manajemen Sumber Daya Manusia, Caps Publishing. Jakarta.

Surakhmad Winarno (2005), Pengantar Penelitian Ilmiah, Tarsito, Bandung.

Suranta, Sri. (2012), Dampak Motivasi Karyawan Pada
Hubungan Antara Gaya Kepemimpinan Dengan Kinerja Pendidik Perusahaan Bisnis. Empirika. Jakarta.

Susilo Martoyo (2005), Manajemen Sumber Daya Manusia, Edisi Kedua, BPFE, Yogyakarta.

Suwatno (2011), Manajemen Sumber Daya Manusia, Alfabeta. Jakarta.

Tampubolon, Biatna. D. (2007), Analisis Faktor Gaya Kepemimpinan Dan Faktor Etos Kerja Terhadap Kinerja Pegawai Pada Organisasi Yang Telah Menerapkan SNI 19-9001-2001,Jurnal Standardisasi. Jakarta.

Tohardi, Ahmad (2012), Pemahaman Praktis Manajemen Sumber Daya Manusia, Mandar Maju. Jakarta.

Triyono, Ayon (2012), Paradigma Baru Sumber Daya Manusia, Oryza. Jakarta.

Triton Prawira Budi (2006), SPSS 13.0 Terapan, Riset Statistik Parametrik, Yogyakarta.

Andi,

Wilson, Bangun J.B. (2011), Manajemen Sumber Daya Manusia, Erlangga.Jakarta.

Winardi (2005). Manajemen Supevisi, Penerbit Mandar Maju, Bandung. 
Wirawan (2012), Manajemen Sumber Daya Manusia, Salemba Empat.Jakarta.

https://emperordeva.wordpress.com/ about/sdm-indonesiadalam-persaingan-global. diakses Jumat, 27 Januari 2017, pukul 20.05

https://finance.detik.com/beritaekonomi-bisnis/d-3107891 diakses Jumat, 27 Januari 2017, pukul 20.20) 